\title{
Genetic and Morphological Variability among the Isolates of Fusarium oxysporum f. sp. lentis causing Wilt of Lentil
}

Anshul Arya', Sujata Singh², K.P.S. Kushwaha ${ }^{3}$, Yogita Bohra ${ }^{4}$, Arun Kushwaha ${ }^{3}$, Roopali Sharma ${ }^{3}$

10.18805/LR-4681

\begin{abstract}
Background: Lentil wilt is one of the most important diseases of lentil directly contributing to the yield losses of the crop. It is caused by Fusarium oxysporum f. sp. lentis which shows the great genetic and morphological diversity.

Methods: Present investigation was conducted during 2017-2019 with 22 isolates of the pathogen, collected from lentil grown areas of Uttarakhand and Uttar Pradesh to explore genetic and morphological variability employing eight ISSR and five SSR primers.

Result: The isolates showed huge morphological variability based on the color, pigmentation and shape of conidia. Study on molecular variability revealed the versatility in the genome of different isolates of pathogen. The diversity among the isolates of pathogens collected from Uttarakhand and Uttar Pradesh was also evident. Generated work on genetic and morphological variability and the population diversity among the different isolates of the pathogen impact on developing ideal disease management strategies.
\end{abstract}

Key words: AMOVA, Diversity, Fusarium oxysporum f. sp. lentis (Fol), ISSR primers, SSR primers, Variability, Wilt.

\section{INTRODUCTION}

Lentil (Lens culinaris) is the most nutritious pulse after chickpea. It is mostly cultivated in in north-east and central parts of India during Rabi season. It is commonly damaged by vascular wilt caused by Fusarium oxysporum f.sp. lentis in all lentil grown regions. Wider adaptability of the pathogen strongly indicates the probability of existence of variants. Molecular and morphological variability in different lentil grown areas is in reports (Datta et al., 2011; Mohammadi et al., 2011; Rafique et al., 2015; Al-Husien et al., 2016). Molecular assay using ISSR primers (Mohammadi et al. 2011; Al-Husien et al. 2017) and SSR primers (Al-Husien et al. 2017) were also done earlier. Variability is always a desirable trait of a pathogen as it helps in the survival of the pathogen under different niche and competition. Identification of variability helps in designing of suitable management to combat multiple pathogenic variants. Hence, the present investigation was conducted to study the genetic and morphological variability among the isolates of Fusarium oxysporum f. sp. lentis in two diverse population of lentil growing areas of Uttarakhand and Uttar Pradesh.

\section{MATERIALS AND METHODS}

Collection, isolation and identification of pathogen and its isolates

Twenty-two isolates of the pathogen were collected from two different states viz; Uttarakhand and Uttar Pradesh given in Table 1. The collected samples were brought to the Pulse Pathology Laboratory at Govind Ballabh Pant University of Agriculture and Technology, Pantnagar, Udham Singh Nagar. Isolation was done from the infected root zone of the plant samples. Isolates were further purified with the "Single Spore Isolation" method given by Zhang et al. (2013). Cultural
${ }^{1}$ Krishi Vigyan Kendra, Jakhdhar, Rudraprayag-246 439, Uttarakhand, India.

${ }^{2}$ Department of Plant Protection, CSIR- Central Institute of Medicinal and Aromatic Plants, Lucknow-226 002, Uttar Pradesh, India.

${ }^{3}$ Department of Plant Pathology, Govind Ballabh Pant University of Agriculture and Technology, Pantnagar-263 145, Udham Singh Nagar, Uttarakhand, India.

${ }^{4}$ Department of Plant Pathology, Punjab Agricultural University, Ludhiana-141 027, Punjab, India.

Corresponding Author: Anshul Arya, Krishi Vigyan Kendra, Jakhdhar, Rudraprayag-246 439, Uttarakhand, India.

Email: anshularyapp.23@gmail.com

How to cite this article: Arya, A., Singh, S., Kushwaha, K.P.S., Bohra, Y., Kushwaha, A. and Sharma, R. (2021). Genetic and Morphological Variability among the Isolates of Fusarium oxysporum f. sp. lentis causing Wilt of Lentil. Legume Research. DOI: $10.18805 /$ LR-4681.

Submitted: 01-06-2021 Accepted: 06-10-2021 Online: 19-11-2021

identification along with the molecular identification of the pathogen was also done. ITS primer i.e. ITS1 (CTTGGTCAT TTAGAGGAAGTAA) and ITS4 (TCCTCCGCTTATTGATATGC) were used for molecular identification purpose.

\section{Morphological characterization of the pathogen isolates}

The isolates were characterized morphologically based on visual colonial characters and microscopy of mycelia and conidia.

\section{Molecular characterization of the pathogen isolates} using ISSR and SSR PCR amplification

Twenty two isolates of $\mathrm{Fol}$ were molecularly characterized by using the eight ISSR (Table 2) and five SSR (Table 3) 
primers synthesized by Eurofins Genomics India Pvt. Ltd. The experiment was conducted in the laboratory of International School of Biocontrol in the dept. of Plant Pathology, GBPUAT, Pantnagar. Amplification of DNA during $P C R$ reaction using ISSR primers was accomplished by using reaction mixtures (DNA template (50 $\mathrm{ng} / \mu \mathrm{l}$ conc.), dNTPs mix (1 mM each conc.), Taq DNA Polymerase (2.5U/ $\mu$ l conc.), Reaction buffer (1X), $\mathrm{Mgcl}_{2}$ (2mM conc.), primer (40 ng) and deionized water (12.9 ml)) with total 40 PCR cycles (Denaturation at $95^{\circ} \mathrm{C}$ for 5 minutes, Annealing at $48.0-55.0^{\circ} \mathrm{C}$ for $1 \mathrm{~min}$ and Polymerization at $72^{\circ} \mathrm{C}$ for 6 min). Similarly, the reaction mixture (DNA template $(25 \mathrm{ng} / \mu \mathrm{l})$, dNTPs mix (0.2 mM), Taq DNA Polymerase (0.6U), Reaction buffer (1x), MgC12 (0.2 mM), Reverse Primer (25 ng/ $\mu \mathrm{l})$, Forward primer $(25 \mathrm{ng} / \mu \mathrm{l})$ and Deionized water $(12.9 \mathrm{ml})$ for SSR primers was also prepared. The PCR amplification of the DNA for SSR primers were completed in 30 cycles (Denaturation: at $94^{\circ} \mathrm{C}$ for 30 seconds, Annealing $51.0^{\circ} \mathrm{C}$ for 40 seconds and polymerization $72^{\circ} \mathrm{C}$ for 30 second). The analysis of the recorded data was done by counting of the reproducible and clear bands with binary digit code "1"(present) and " 0 " (absent) for presence and absence of the bands. Jaccard's Similarity coefficients was generated using presence and absence of unique and shared and polymorphic bands with the use of NTSYS 2.01 Software (Rholf 1993). On the basis of Similarity coefficient dendrogram was made manually by UPGMA (Unweighted Pair- Group Method with Arithmetical Averages).

Jacquard's similarity coefficient was the basis for analysis and given as follows:

Similarity coefficient $=\frac{\text { No. of polymorphic bands }}{\text { Total no. of bands }}$

Polymorphic information content (PIC) provides an estimate of the discriminatory power of a locus or loci, by taking into account, not only the number of alleles that are expressed, but also relative frequencies of those alleles (Kumar et al. 2003). The following formula was used for the estimation:

Where,

$$
\mathrm{PICi}=1-1 / \mathrm{n} \sum_{\mathrm{i}=1}^{\mathrm{n}} \mathrm{Pij}
$$

$\mathrm{Pij}$ is the frequency of $\mathrm{j}^{\text {th }}$ allele in the $\mathrm{i}^{\text {th }}$ primer, $\mathrm{n}$ is the total number of alleles expressed by $i^{\text {th }}$ primer.

\section{Study on the genetic diversity of the population}

The study on the genetic diversity of the two population was also done using the GENALEX Software and AMOVA.

\section{RESULTS AND DISCUSSION \\ Identification of pathogen and its isolates}

The identity of pathogenic isolate FOL3 (Pantnagar isolate) was confirmed with BLASTn report at NCBI site (Fig 1) and accession no. MK452341 was obtained for the sequence. Rest of the isolates showed the amplicon size $\approx 750 \mathrm{bp}$ which was found same as the sequenced isolate.

\section{Morphological Characterization of the pathogen isolates}

There were two types of mycelial growth pattern such as appressed growth where mycelium was less developed showing sparse growth and fluffy growth where mycelium was well developed and have a dense appearance (Table 1, Fig 2). The color and pigmentation of the colony varied from white, yellow, purple, olive green, pink and wine color. Among 22 isolates collected, 15 were found fast-growing followed by six isolates showing medium growth rate and one isolate had a slow growth rate (Table 1). All the collected isolates showed three types of conidia of different size and shape. All collected isolates produced abundant microconidia in culture and size of the microconidia varied from $1.47 \mu \mathrm{m} \mathrm{x}$ $1.05 \mu \mathrm{m}$ to $5.43 \mu \mathrm{m} \times 1.21 \mu \mathrm{m}$. Isolates showed variety in

\begin{tabular}{|c|c|c|c|c|c|c|c|}
\hline \multicolumn{2}{|r|}{ if Alignments A Download a GenBank Graphics Distance tree of results } & & & & & & क \\
\hline & Description & $\begin{array}{l}\text { Max } \\
\text { Score }\end{array}$ & $\begin{array}{l}\text { Total } \\
\text { Score }\end{array}$ & $\begin{array}{l}\text { Query } \\
\text { Cover }\end{array}$ & \begin{tabular}{|c|}
$E$ \\
value
\end{tabular} & $\begin{array}{l}\text { Per. } \\
\text { Ident }\end{array}$ & Accession \\
\hline$\square$ & Fusarium sp. $1 \mathrm{~B} 150$ 18S ribosomal RNA gene. partial sequence; internal transcribed spacer $1.5 .8 \mathrm{~S}$ ribosomal RNA gene, and internal trans scribed spacer 2 , complete seq! & 979 & 979 & $94 \%$ & 0.0 & $99.45 \%$ & $\underline{K R 812233.1}$ \\
\hline$\square$ & Fusarium oxysporum isolate FUS-33 small subunit ribosomal RNA gene, partial sequence: internal transcribed spacer 1.5 .85 ribosomal RNA gene, and internal transcriber & 977 & 977 & $94 \%$ & 0.0 & $99.44 \%$ & MH879861.1 \\
\hline$\square$ & Fusarium oxysporum isolate FUS-29-1 small subunit ribosomal RNA gene, partial sequence, internal transcribed spacer $1,5.8 \mathrm{~S}$ ribosomal RNA gene, and internal transcrib & 977 & 977 & $94 \%$ & 0.0 & $99.44 \%$ & MH879586.1 \\
\hline$\square$ & Fusarium oxysporum isolate FJAT-31092 $18 \mathrm{~S}$ ribosomal RNA gene, partial sequence, internal transcribed spacer $1.5 .8 \mathrm{~S}$ ribosomal RNA gene, and internal transcribed spa & 977 & 977 & $94 \%$ & 0.0 & $99.44 \%$ & $\underline{\text { KU931543.1 }}$ \\
\hline$\square$ & Fusarium oxvsporum intemal transcribed spacer 1 , partial sequence: $5.8 \mathrm{~S}$ ribosomal RNA gene and internal transcribed spacer 2 . complete sequence: and $28 \mathrm{~S}$ ribosomalf & 977 & 977 & $97 \%$ & 0.0 & $98.73 \%$ & KJ.J54902.1 \\
\hline$\square$ & Fusarium oxysporum isolate TA pink1 small subunit ribosomal RNA gene, partial sequence: internal transcribed spacer $1.5 .8 \mathrm{~S}$ ribosomal RNA gene, and internal transcrib & 976 & 976 & $94 \%$ & 0.0 & $99.44 \%$ & MK156696.1 \\
\hline$\square$ & Fusarium oxysporum voucher CRM-ACTLR31 small subunit ribosomal RNA gene, partial sequence. intermal transcribed spacer $1,5.8 \mathrm{~S}$ ribosomal RNA gene. and internalt & 976 & 976 & $94 \%$ & 0.0 & $99.44 \%$ & MK396894.1 \\
\hline$\square$ & Fusarium oxysporum isolate FJAT-31091 $18 \mathrm{~S}$ ribosomal RNA gene, partial sequence: internal transcribed spacer 1.5.8S ribosomal RNA gene, and internal transcribed spa & 976 & 976 & $94 \%$ & 0.0 & $99.44 \%$ & $\underline{\text { KU931542.1 }}$ \\
\hline$\square$ & Fusarium sp. strain P1754 $18 \mathrm{~S}$ ribosomal RNA gene, partial sequence. internal transcribed spacer $1.58 \mathrm{~S}$ ribosomal RNA gene, and internal transcribed spacer 2 , complett & 976 & 976 & $94 \%$ & 0.0 & $99.44 \%$ & $\underline{\mathrm{KT} 269026.1}$ \\
\hline$\square$ & Fusarium oxysporumf. cubense strain tropical race 4 isolate WBKBCKV2 small subunit ribosomal RNA gene, partial sequence, internal transcribed spacer $1,5.8 \mathrm{~S}$ ribosom & 974 & 974 & $94 \%$ & 0.0 & $99.44 \%$ & $\underline{\text { MH454072.1 }}$ \\
\hline$\square$ & Fusarium oxysporum strain .ss 142 small subunit ribosomal RNA gene, Daartial sequence: internal transcribed spacer $1.5 .8 \mathrm{~S}$ ribosomal RNA gene, and internal transcribed & 974 & 974 & $95 \%$ & 0.0 & $99.26 \%$ & $\underline{\mathrm{MH} 290453.1}$ \\
\hline$\square$ & Fusarium oxysporum isolate $12 \mathrm{PDA}$-Vald $18 \mathrm{~S}$ ribosomal RNA gene, partial sequence; internal transcribed spacer $1.5 .8 \mathrm{~S}$ ribosomal RNA gene, and internal transcribed spa & 974 & 974 & $95 \%$ & 0.0 & $99.08 \%$ & $\underline{\mathrm{k} \times 343146.1}$ \\
\hline$\square$ & Fusarium cf. oxysporum B164 $18 \mathrm{~S}$ ribosomal RNA gene, partial sequence: internal transcribed spacer $1.5 .8 \mathrm{~S}$ ribosomal RNA gene, and internal transcribed spacer 2 .com। & 974 & 974 & $94 \%$ & 0.0 & $99.26 \%$ & KR812231.1 \\
\hline$\square$ & Fusarium oxysporum strain DTJ1(1) $18 \mathrm{~S}$ ribosomal RNA gene, partial sequence: intermal transcribed spacer $1.5 .8 \mathrm{~S}$ ribosomal RNA gene, and intermal transcribed spacer 2 & 974 & 974 & $94 \%$ & 0.0 & $99.26 \%$ & KM268664.1 \\
\hline$\square$ & Fusarium oxysporum isolate AM52 small subunit ribosomal RNA gene, partial sequence: internal transcribed spacer $1.5 .8 \mathrm{~S}$ ribosomal RNA gene, and internal transcribeds & 972 & 972 & $95 \%$ & 0.0 & $98.90 \%$ & $\underline{\mathrm{MH} 509411.1}$ \\
\hline$\square$ & Fusarium oxysporum strain FAZ125-3-2 small subunit ribosomal RNA gene, partial sequence: internal transcribed spacer $1.5 .8 \mathrm{~S}$ ribosomal RNA gene, and internal transcrit & 972 & 972 & $94 \%$ & 0.0 & $99.26 \%$ & MK157025.1 \\
\hline$\square$ & Fusarium oxysporum strain FAZ121-5 small subunit ribosomal RNA gene. partial sequence, internal transcribed spacer $1.5 .8 \mathrm{~S}$ ribosomal RNA gene, and internal transcribe & 972 & 972 & $94 \%$ & 0.0 & $99.26 \%$ & MK156762.1 \\
\hline$\square$ & Fusarium oxysporum isolate FUS-20 small subunit ribosomal RNA gene, partial sequence, internal transcribed spacer $1.5 .8 \mathrm{~S}$ ribosomal RNA gene, and internal transcriber & 972 & 972 & $94 \%$ & 0.0 & $99.26 \%$ & MH879859.1 \\
\hline 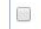 & Fusarium oxysporum genomic DNA sequence contains ITS1 $5.8 \mathrm{~S}$ rRNA gene. ITS2.28S rRNA gene, isolate OrSaAg1 & 972 & 972 & $94 \%$ & 0.0 & $99.26 \%$ & LT T970803.1. \\
\hline
\end{tabular}

Fig 1: BLASTn results output on NCBI that shows similarities of sample with Fusarium sp. 
the size and shapes of the conidia and chlamydospores. Chlamydospores were produced intercalary and terminally from the mycelium as described by Vasudeva and Srinivasan (1952). The shape of chlamydospores observed was round and oval. The sizes of the chlamydospores were also found significantly different from each other and varied in a range from $1.45 \times 2.82 \mu \mathrm{m}$ to $9.32 \times 2.16 \mu \mathrm{m}$. The results recorded are in agreement with report of variability in terms of their growth pattern and pigmentation as described by Kannaiyan and Nene (1978) who isolated the different isolates of Fusarium oxysporum f.sp. lentis.

\section{Genetic variability in the pathogen isolates employing ISSR Primers and SSR Primers}

The temperature required for the annealing of the primers is listed in Table 2 ranged from 48 to $55^{\circ} \mathrm{C}$. Maximum annealing temperature required by the primer ISSR 10 was $55^{\circ} \mathrm{C}$, A range of 50 to $55^{\circ} \mathrm{C}$ for the isolates of $\mathrm{Foc}$ was recorded by Rakhonde et al. (2017). Total 81 loci were amplified by eight ISSR primers. The maximum of 12 loci was amplified by three primers named as GAC, PRIMER3 and ISSR10. All the amplified sites were polymorphic none was found monomorphic. The bands obtained were of

Table 1: Morphological and cultural characteristics of the isolates of Fusarium oxysporum f.sp. lentis on the PDA medium.

\begin{tabular}{|c|c|c|c|c|c|c|c|c|c|c|}
\hline $\begin{array}{l}\text { Isolate } \\
\text { Desig- } \\
\text {-nation }\end{array}$ & Place & $\begin{array}{l}\text { Colony } \\
\text { dia. } \\
(\mathrm{cm})\end{array}$ & $\begin{array}{l}\text { Growth } \\
\text { pattern }\end{array}$ & $\begin{array}{c}\text { Growth } \\
\text { rate }\end{array}$ & $\begin{array}{c}\text { Mycelial } \\
\text { color }\end{array}$ & $\begin{array}{l}\text { Pigmen- } \\
\text {-tation }\end{array}$ & Margin & $\begin{array}{c}\text { Av. size } \\
\text { of micro- } \\
\text { conidia }(\mu \mathrm{m})\end{array}$ & $\begin{array}{c}\text { Av. Size } \\
\text { of macro- } \\
\text { conidia }(\mu \mathrm{m})\end{array}$ & $\begin{array}{c}\text { Av. Size of } \\
\text { chlamydo } \\
\text { spores }(\mu \mathrm{m})\end{array}$ \\
\hline FOL1 & Gaulapar & 8.97 & Fluffy & Fast & White & Blue & Circular & $3.23 \times 1.40$ & $6.27 \times 1.12$ & $2.17 \times 3.20$ \\
\hline FOL2 & Chitora & 8.90 & Fluffy & Fast & Pale white & Yellow & Irregular & $3.97 \times 0.90$ & $8.50 \times 1.25$ & $7.09 \times 2.78$ \\
\hline FOL3 & Pantnagar & 9.00 & Fluffy & Fast & White & Purple & Circular & $2.78 \times 1.40$ & $11.06 \times 1.64$ & $3.46 \times 5.74$ \\
\hline FOL4 & Tulahat & 9.00 & Appressed & Fast & White & Blue & Circular & $3.38 \times 1.22$ & $19.33 \times 2.04$ & $2.21 \times 1.46$ \\
\hline FOL5 & Shantipuri & 8.97 & Fluffy & Fast & White & Absent & Circular & $2.55 \times 1.02$ & $7.63 \times 1.08$ & $2.98 \times 1.67$ \\
\hline FOL6 & Ramnagar & 8.50 & Fluffy & Fast & White & Pink & Circular & $.35 \times 1.05$ & $8.35 \times 1.32$ & $3.88 \times 2.47$ \\
\hline FOL7 & Gadarpur & 7.90 & Fluffy & Medium & White & Purple & Circular & $2.67 \times 0.73$ & $6.75 \times 1.06$ & $3.20 \times 3.04$ \\
\hline FOL8 & Pithoragarh & 9.00 & Fluffy & Fast & White & Blue & Circular & $3.21 \times 0.86$ & $5.84 \times 0.8 .0$ & $3.34 \times 2.54$ \\
\hline FOL9 & Kathgariya & 8.53 & Fluffy & Fast & White & Absent & Circular & $2.62 \times 1.07$ & $10.21 \times 1.37$ & $9.32 \times 2.16$ \\
\hline FOL10 & Purola & 9.00 & Fluffy & Fast & Yellow & Yellow & Irregular & $4.76 \times 1.38$ & $19.08 \times 2.63$ & $2.45 \times 7.69$ \\
\hline FOL11 & Kichcha & 8.90 & Fluffy & Fast & White & Purple & Circular & $2.99 \times 0.64$ & $5.83 \times 0.75$ & $4.94 \times 1.96$ \\
\hline FOL12 & Bhowali & 7.70 & Fluffy & Medium & Pink & Wine & Irregular & $2.78 \times 0.78$ & $10.20 \times 2.05$ & $2.97 \times 4.44$ \\
\hline FOL13 & Bageshwar & 8.53 & Fluffy & Fast & Pink & Wine & Irregular & $2.98 \times 1.15$ & $9.19 \times 1.59$ & $6.61 \times 2.46$ \\
\hline FOL14 & Rudrapur & 9.00 & Fluffy & Medium & White & Absent & Circular & $2.27 \times 1.25$ & $6.00 \times 1.66$ & $3.28 \times 4.39$ \\
\hline FOL15 & Bareilly & 9.00 & Fluffy & Fast & White & Blue & Circular & $3.27 \times 0.88$ & $5.53 \times 1.12$ & $1.45 \times 2.81$ \\
\hline FOL16 & Bazpurr & 4.73 & Appressed & Slow & Olive & Absent & Irregular & $1.47 \times 1.05$ & $7.64 \times 1.35$ & $2.31 \times 0.89$ \\
\hline FOL17 & Kanpur & 9.00 & Fluffy & Fast & White & Pink & Circular & $1.69 \times 0.47$ & $12.27 \times 1.05$ & $2.67 \times 1.67$ \\
\hline FOL18 & Halduchaur & 9.00 & Fluffy & Fast & White & Purple & Circular & $5.43 \times 1.21$ & $20.37 \times 1.67$ & $2.84 \times 2.21$ \\
\hline FOL19 & Dhampur & 8.63 & Appressed & Fast & White & Purple & Circular & $2.86 \times 1.38$ & $8.99 \times 0.78$ & $2.84 \times 1.96$ \\
\hline FOL20 & Kotwali & 7.17 & Appressed & Medium & White & Brown & Irregular & $3.95 \times 0.84$ & $7.46 \times 0.73$ & $3.69 \times 1.54$ \\
\hline FOL21 & Baheri & 6.00 & Fluffy & Medium & White & Absent & Circular & $3.31 \times 1.04$ & $7.60 \times 1.12$ & $2.73 \times 3.36$ \\
\hline FOL22 & Naugaon & 7.27 & Fluffy & Medium & White & Pink & Circular & $2.54 \times 0.68$ & $10.12 \times 1.39$ & $2.00 \times 2.53$ \\
\hline
\end{tabular}

Table 2: Annealing temperature and $\mathrm{G}+\mathrm{C}$ content of ISSR primers and per cent polymorphism and amplified alleles observed with ISSR primers.

\begin{tabular}{|c|c|c|c|c|c|c|c|c|c|c|}
\hline Primer & Primer sequence $\left(5^{\prime}\right.$ to $\left.3^{\prime}\right)$ & $\begin{array}{c}\mathrm{G}+\mathrm{C} \\
\text { content } \\
(\%)\end{array}$ & $\begin{array}{c}\text { Annealing } \\
\text { temperature } \\
\left({ }^{\circ} \mathrm{C}\right)\end{array}$ & $\begin{array}{c}\text { Total } \\
\text { no. of } \\
\text { loci/NTA }\end{array}$ & $\begin{array}{c}\text { Mono- } \\
\text {-morphic } \\
\text { bands }\end{array}$ & $\begin{array}{c}\text { Polymorphic } \\
\text { Bands } \\
\text { /NPA }\end{array}$ & $\begin{array}{c}\% \\
\text { polymor- } \\
\text {-phism }\end{array}$ & $\begin{array}{l}\text { Unique } \\
\text { bands }\end{array}$ & PIC & $\mathrm{RP}$ \\
\hline (CAG)5 & CAGCAGCAGCAGCAG & 53.3 & 52 & 10 & 0 & 10 & 100 & 0 & 0.34 & 5.27 \\
\hline Primer 2 & GACGACGACGACGAC & 66.7 & 54 & 8 & 0 & 8 & 100 & 1 & 0.33 & 4.54 \\
\hline GAC & GACGACGACGACGAC & 66.7 & 51 & 12 & 0 & 12 & 100 & 1 & 0.39 & 6.81 \\
\hline (GTG) 5 & GTGGTGGTGGTGGTG & 66.7 & 54 & 10 & 0 & 10 & 100 & 1 & 0.29 & 3.72 \\
\hline Primer3 & GTGGTGGTGGTGGTG & 66.7 & 51 & 12 & 0 & 12 & 100 & 1 & 0.37 & 6.54 \\
\hline ISSR10 & CACCACCACCACCAC & 66.7 & 55 & 12 & 0 & 12 & 100 & 0 & 0.30 & 4.36 \\
\hline LC48 & AGAGAGAGAGAGAGAGG & 52.9 & 48 & 7 & 0 & 7 & 100 & 0 & 0.32 & 3.00 \\
\hline \multirow[t]{2}{*}{ LC49 } & GAGAGAGAGAGAGAGAT & 47.1 & 49 & 10 & 0 & 10 & 100 & 0 & 0.29 & 4.18 \\
\hline & Average & & & 10.12 & - & 10.12 & 100 & - & 0.76 & \\
\hline
\end{tabular}


different sized ranged approximately from $0.1 \mathrm{~Kb}$ to $2 \mathrm{Kbp}$ as revealed in Table 2. Mohammadi et al. (2011) recorded the size of amplicons ranged from 0.15 to $3.5 \mathrm{~Kb}$, generated by the PCR amplification through ISSR primers among the $F O L$ isolates depending on the primers and isolate combinations and a total of 70 loci were amplified by using the ISSR primers. The maximum PIC value 0.39 was recorded in GAC that showed the high level of polymorphism. The primers (GTG)5 (0.29) and LC49 (0.29) were found at par with each other. The resolving power (RP) for the each primer was varied and ranged from 6.81 to 3.00 . The maximum resolving power was observed for the primer GAC

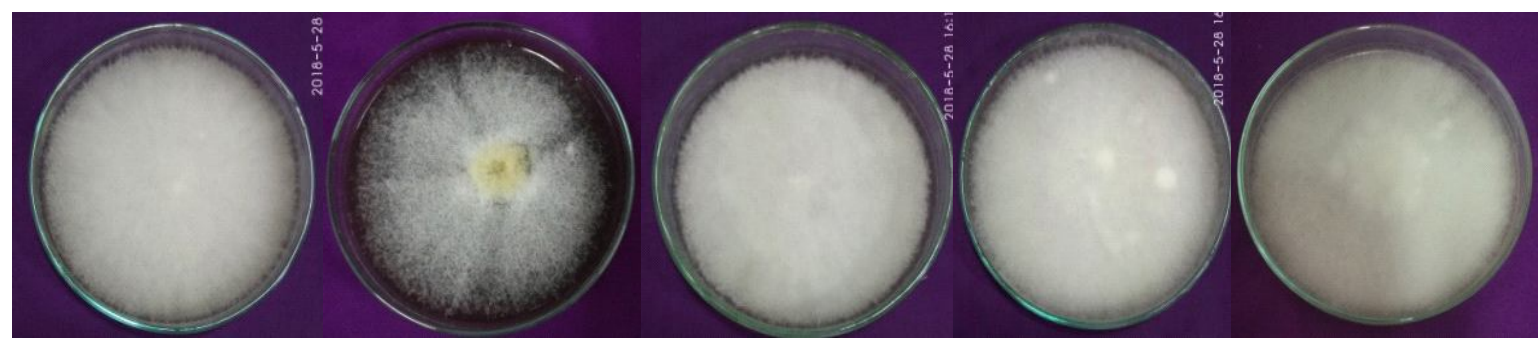

FOL1

FOL2

FOL3

FOL4

FOL5

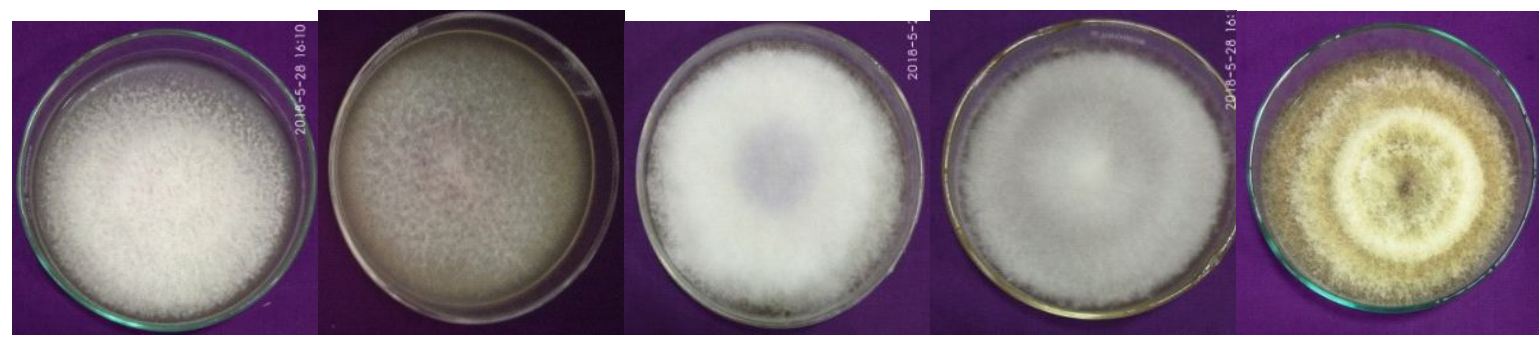

FOL6

FOL 7

FOL 8

FOL 9

FOL 10

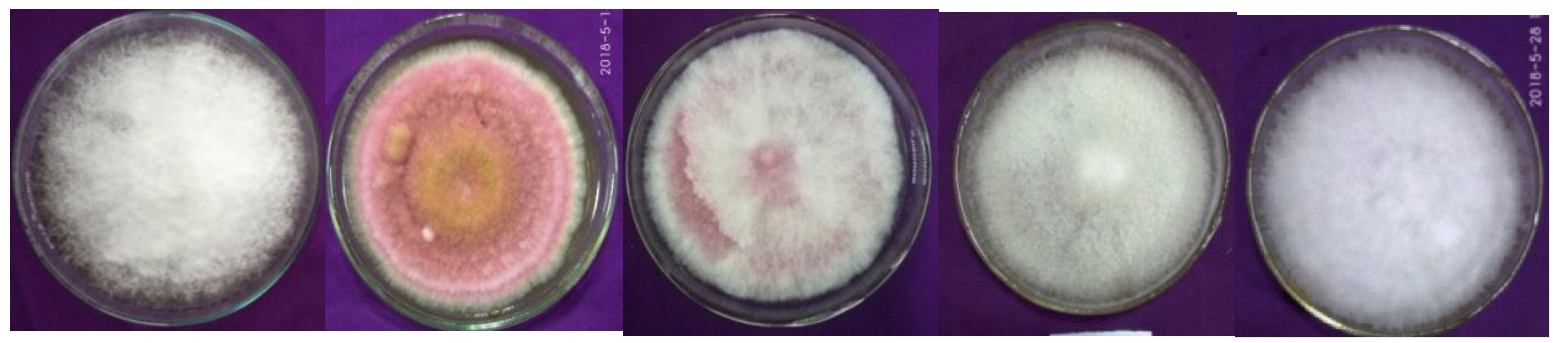

FOL 11

FOL 12

FOL 13

FOL14

FOL 15

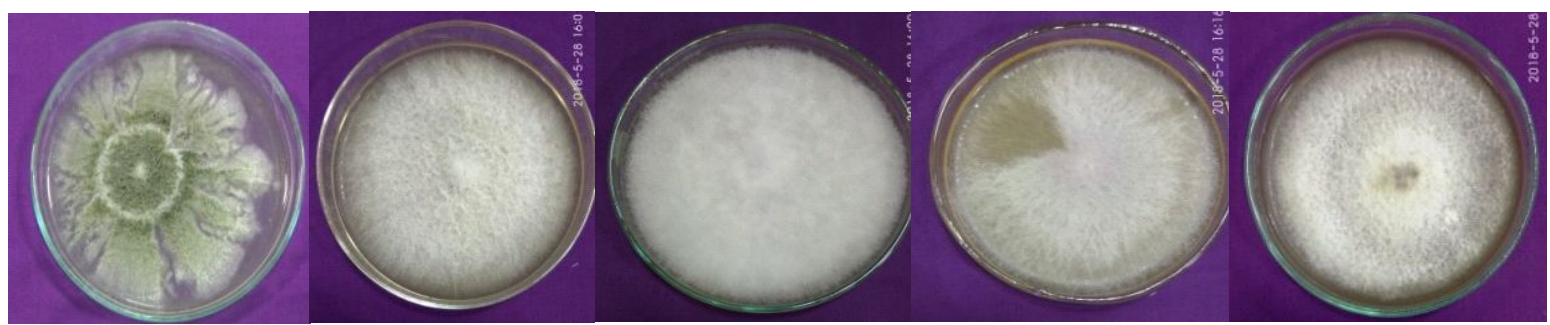

FOL 16

FOL 17

FOL 18

FOL 19

FOL 20

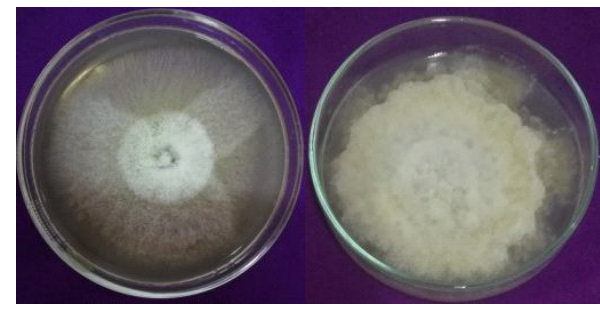

FOL 21

FOL22

Fig 2: Cultural variability of different isolates of Fusarium oxysporum f.sp. lentis; (Fol: Fusarium oxysporum f.sp. lentis). 
i.e. 6.81. Little work is done on the variability of lentil wilt pathogen using ISSR primers and results obtained by Mohammadi et al. (2011) revealed the mean PIC value of ISSR primers for Fusarium oxysporum f.sp. lentis isolates as 0.234 . The results revealed that the genetic variation is present among the isolates of the Fusarium oxysporum f.sp. lentis using ISSR primers. All the ISSR primers used produced the scorable bands with a high degree of polymorphism. The percent of the polymorphism was hundred percent in all the ISSR primers. Some primers also produced unique bands at different loci.

The minimum similarity coefficient obtained was 0.51 and maximum similarity coefficient obtained was 0.87 . The results of pairwise combination indicated the closest relationship between the isolates FOL4 and FOL5 i.e. 0.87 followed by the isolates FOL18 and FOL16 (0.82) and between the isolates FOL5, FOL3 and FOL4 (0.81). The minimum similarity coefficient or maximum diversity was observed in between the isolates FOL3, FOL13 and FOL15 i.e. 0.51.

Based on Jaccard's similarity matrix, dendrogram (Fig 3) was drawn using SAHN option. Twenty-two isolates at 62 percent similarity level were clustered in the two major clusters (A and $B$ ). Cluster A consisted nine isolates. Cluster $A$ is further separated into four sub-clusters, similarly, cluster $B$ was also sub clustered into four sub-clusters. The present study revealed that the ISSR primers are useful for the detection of genetic variation among the isolates of Fusarium oxysporum f.sp. lentis. The recent studies on the genetic diversity showed a high degree of genetic variation among the isolates of the Fusarium oxysporum f.sp. lentis from lentil.

All the SSR primers, except primer MB5F and MB5R, produced the scorable bands with the isolates. The region

Table 3: Annealing temperature and the $\mathrm{G}+\mathrm{C}$ content of SSR primers and percent polymorphism and amplified bands observed in the SSR primers.

\begin{tabular}{|c|c|c|c|c|c|c|c|c|c|}
\hline Primer & Primer sequence ( $5^{\prime}$ to $\left.3^{\prime}\right)$ & $\begin{array}{c}\mathrm{G}+\mathrm{C} \\
\text { content } \\
(\%)\end{array}$ & $\begin{array}{c}\text { Annealing } \\
\text { temperature } \\
\left({ }^{\circ} \mathrm{C}\right)\end{array}$ & $\begin{array}{c}\text { Ampli- } \\
\text {-fied } \\
\text { loci }\end{array}$ & $\begin{array}{c}\text { Poly- } \\
\text {-morphic } \\
\text { bands }\end{array}$ & $\begin{array}{c}\% \\
\text { poly } \\
\text {-morphism }\end{array}$ & $\begin{array}{c}\text { Mono- } \\
\text {-morphic } \\
\text { bands }\end{array}$ & $\begin{array}{l}\text { Unique } \\
\text { bands }\end{array}$ & PIC \\
\hline MB11F & GTGGACGAACACCTGCATC & 57.9 & 62 & 2 & 2 & 100 & 0 & 0 & 0.68 \\
\hline MB11R & AGATCCTCCACСTCСАССTC & 60.0 & & & & & & & \\
\hline MB13F & GGAGGATGAGCTCGATGAAG & 55.0 & 59 & 4 & 4 & 100 & 0 & 2 & 0.87 \\
\hline MB13R & CTAAGCCTGCTACACCCTCG & 60.0 & & & & & & & \\
\hline MB2F & TGCTGTGTATGGATGGATGG & 50.0 & 62 & 2 & 2 & 100 & 0 & 2 & 0.72 \\
\hline MB2R & CATGGTCGATAGCT & 50.0 & & & & & & & \\
\hline MB18F & GGTAGGAAATGACGAAGCTGAC & 50.0 & 50 & 4 & 4 & 100 & 0 & 3 & 0.76 \\
\hline MB18R & TGAGCACTCTAGCACTCCAAAC & 50.0 & & & & & & & \\
\hline MB5F & ACTTGGAGAAATGGGCTTC & 47.4 & Nil & Nil & Nil & Nil & Nil & Nil & Nil \\
\hline \multirow[t]{2}{*}{ MB5R } & GGATGGAGTTTAATAAATCTGG & 36.4 & & & & & & & \\
\hline & Average & & & 3 & 3 & - & - & - & 0.75 \\
\hline
\end{tabular}

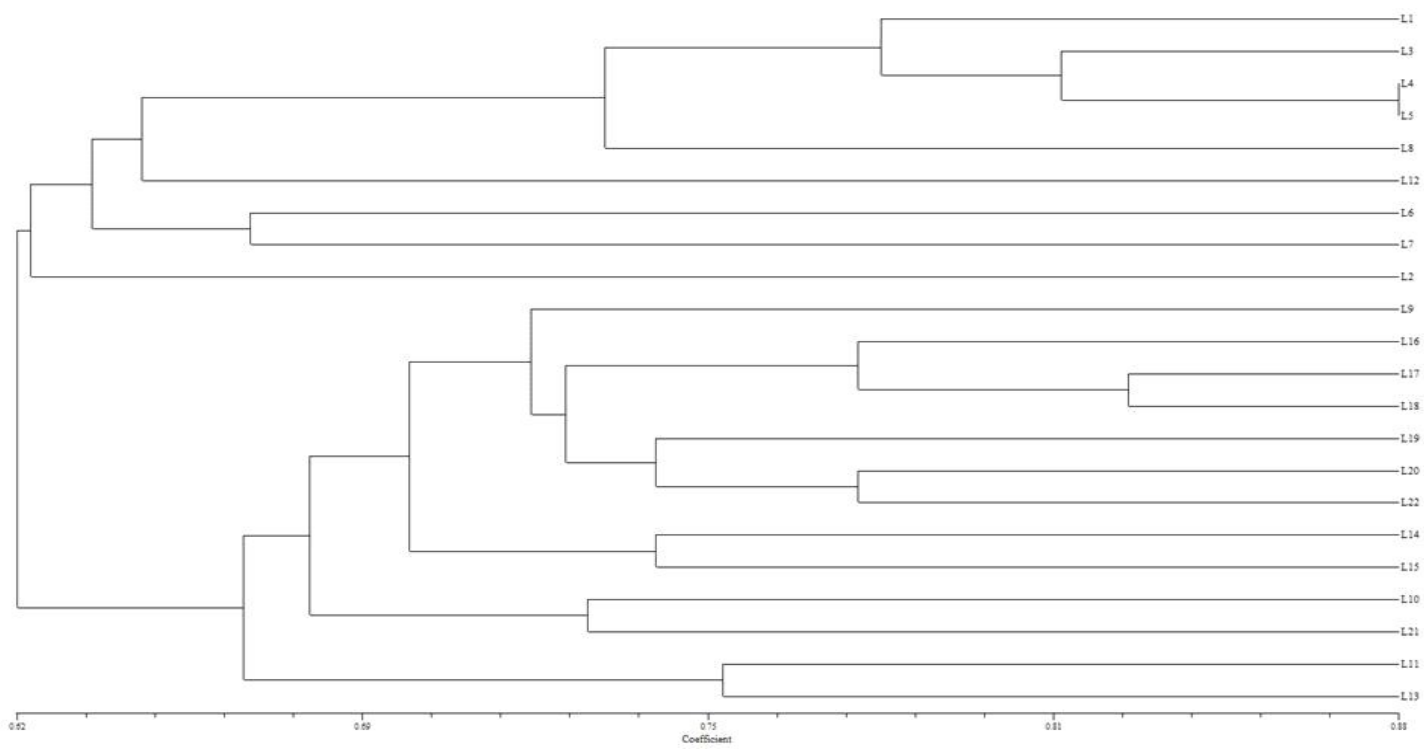

Fig 3: Dendrogram depicting the Classification of 22 Fusarium oxysporum f.sp. lentis isolates constructed using UPGMA method based on ISSR markers. The scale at the bottom is Jaccard' coefficient of genetic similarity. 


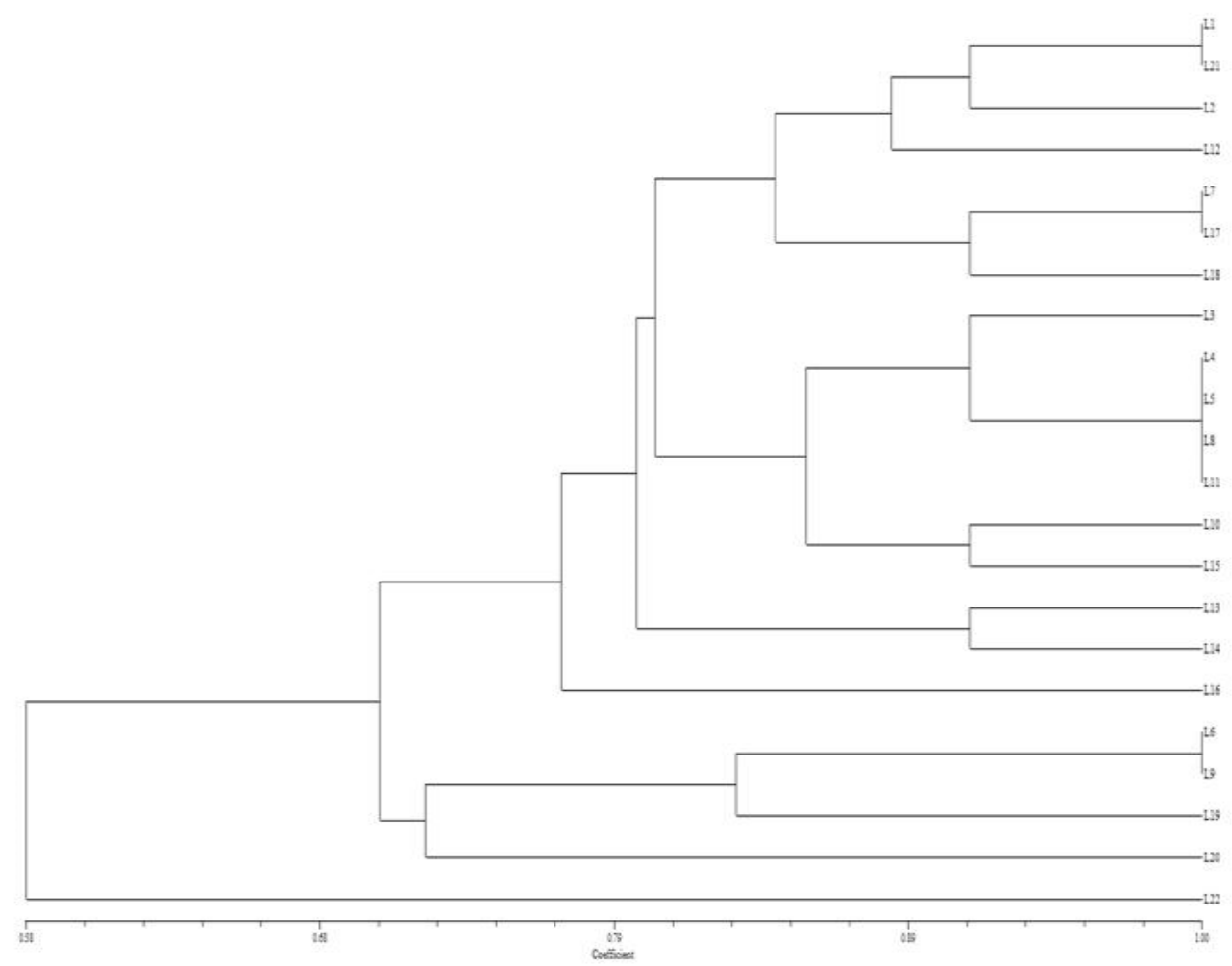

Fig 4: Dendrogram depicting the classification of the 22 Fusarium oxysporum f.sp. lentis isolates constructed using UPGMA method based on SSR markers. The scale at the bottom is Jaccard' coefficient of genetic similarity.

of amplification for this primer was not available in all the isolates. Annealing temperature (Table 3 ) for the primers were found very high i.e. $62^{\circ} \mathrm{C}$ for the primers MB11 and MB2. Eight loci were amplified by the four SSR primers (MB11, MB13, MB2 and MB18). Monomorphic bands were absent for all the primers used. Primers also gave unique bands at different loci. Primer MB13 gave two unique bands of the size 0.3 and $0.4 \mathrm{~kb}$, similarly, Primer MB2 gave two unique bands of the size 0.6 and $0.8 \mathrm{~kb}$. Primer MB18 produced three unique bands of size $0.21,0.25$ and $0.26 \mathrm{~kb}$. The PIC value for the primers varied from 0.68 to 0.87 . The Maximum PIC value 0.87 was observed for the primer MB13. PIC value for the SSR primers varies from 0.0 to 1 and the PIC values showed a high level of genetic variability among the isolates observed. All the isolates exhibited a high degree of polymorphism up to 100 per cent showed that all the isolates used had a high level of genetic variability among them.

The binary data recorded by scoring the bands were used for the analysis of the similarity coefficient as well as the UPGMA. The range of Jaccard's similarity coefficient across the isolates ranged from 0.41 to 1.0 . At 58 percent similarity level, the dendrogram (Fig 4) grouped the isolates into one major cluster 1 with a single isolate FOL22 (Naugaon). Cluster 1 consisted of 21 isolates. The studies were as per the Datta et al. (2011) who found the genetic diversity among the hundred isolates of Fusarium oxysporum f.sp. lentis where SSR primers amplified 21 alleles and a similarity coefficient 73 per cent between two isolates. Al-

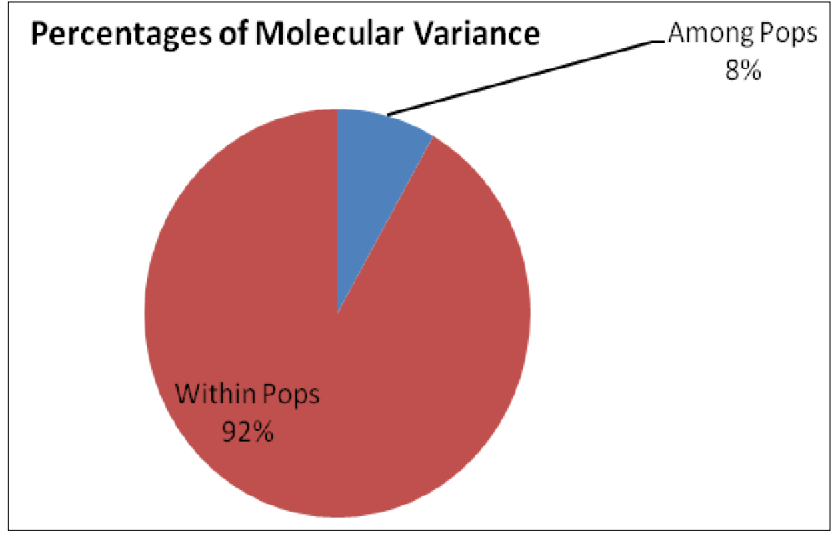

Fig 5: Per cent molecular variance between two populations of Fusarium oxysporum f.sp. lentis.

Husien et al. (2017) reported the genetic diversity among the 96 isolates of Fusarium oxysporum f.sp. lentis in Syria by using SSR, ISSR and RAPD primers.

\section{Genetic diversity among the populations}

The existing genetic diversity was recorded between the two populations of the pathogen collected from Uttarakhand and Uttar Pradesh using GENALEX software. The results showed the huge diversity among the isolates of Uttarakhand. Among the two populations the diversity was found very less i.e. only 8 per cent, however, diversity within the population was found high i.e. 92 per cent (Fig 5). Hence 
it can be concluded that more diversity exists within the individuals of same population and less diversity is reported among the individuals of two populations.

\section{CONCLUSION}

Twenty two isolates of Fusarium oxysporum f.sp. lentis which were isolated from lentil growing areas of Uttarakhand and Uttar Pradesh showed the maximum genetic variability within the population rather than between the populations. The isolates showed morphological as well as genetic variability. The presence of variability among the isolates revealed that there is huge need of development of new resistant varieties as well as the management strategies those can combat all the existing isolates of the pathogen in different lentil growing areas.

\section{REFERENCES}

Al-Husien, N.H., Hamwieh, A., Ahmed, S. and Bayaa, B. (2017). Genetic diversity of Fusarium oxysporum f.sp. lentis population affecting lentil in Syria. Journal of Phytopathology. 165(5): 306-312.

Datta, S., Choudhary, R.G., Shamim, M., Singh, R.K. and Dhar, V. (2011). Molecular diversity in Indian isolates of Fusarium oxysporum f.sp. lentis inciting wilt disease in lentil (Lens culinaris Medik). African Journal of Biotechnology. 10(38): 7314-7323.
Kannaiyan, J. and Nene, Y.L. (1978b). Host range of Fusarium oxysporum f.sp. lentis and their pathogenicity on some lentil lines. LENS Newsletter. 5: 8-10.

Kumar, P., Freeman, A.R., Loftus, R.T, Gallard, C., Fuller, D.Q. and Bradley, D.G. (2003). Admixture analysis of South Asian Cattle. Heredity. 91: 43-50.

Mohammadi, N., Goltapeh, E.M., Dolatabadi, H.K., Ahari, A.B. and Pouralibaba, H.R. (2011). The genetic diversity of Iranian isolates causing Fusarium wilt of lentil. International Journal of Agricultural Technology. 7(6): 1809-1822.

Rafique, K., Rauf, C.A., Naz, F. and Shabbir, G. (2015). DNA sequence analysis, morphology and pathogenicity of Fusarium oxysporum f. sp. lentis isolates inciting lentil wilt in Pakistan. International Journal of Biosciences. 7(6): 74-91.

Rakhonde, P.N., Mane, S.S., Gawande, A.D., Wadskar, R.M., Vyavhare, G.F. and Harne, A.D. (2017). Molecular diversity in Indian isolates of Fusarium oxysporum f.sp. ciceri by ISSR analysis. Journal of Pharmacognosy and Phytochemistry. 6(6S): 195-201.

Rohlf, F.J. (1993). Numerical Taxonomy and Multivariate Analysis System NTSys-PCVersion 1.80 Exeter Software. New York.

Vasudeva, R.S. and Srinivasan, K.V. (1952). Studies on the wilt diseases of lentil (Lens esculenta Moench.). Indian Phytopathology. 5: 23-32.

Zhang, K., Su, Y.Y. and Cai, L. (2013). An optimized protocol of single spore isolation for fungi. Cryptogamie Mycologie. 34(4): 349-356. 